\title{
UPAYA MENINGKATKAN KEMAMPUAN SISWA DALAM MENULIS TEKS MONOLOG PROCEDURE MELALUI METODE DEMONSTRASI
}

\author{
Enjang Haryana \\ SMP Negeri 3 Manonjaya, Jln. Pangangonan Desa Cihaur Kec. Manonjaya Kab. Tasikmalaya, Indonesia. \\ email: enjang_haryana@gmail.com
}

\begin{abstract}
The reality in the field in Class IX-B of SMP Negeri 3 Manonjaya, students have difficulty in writing procedure monologue texts. Thus, to overcome students' difficulties in writing procedure monologue texts, a way is needed to make it easier for students to describe the actual situation through words. One alternative way of writing a procedure monologue is through the demonstration method. Therefore, the purpose of this study is to find out data on improving students' ability to write procedure monologue texts through demonstration methods in learning English in Class IX-B SMP Negeri 3 Manonjaya. The method that will be used in this research is Kemmis and Taggart's Class Action Research (CAR). The subjects in this study were teachers and students of Class IX-B SMP Negeri 3 Manonjaya. The number of students in Class IX-B is 29 people, consisting of 14 boys and 15 girls. The results showed that student learning outcomes about students' ability to write procedure monologue texts through demonstration methods had an effect on improving student learning outcomes. The ability of students to write a procedure monologue text after using the demonstration method in learning English language and literature in Class IX-B SMP Negeri 3 Manonjaya proved to have increased, namely student learning outcomes in the first cycle, namely $74.8 \%$ increased to $82.8 \%$ in the second cycle.
\end{abstract}

Keywords: Ability, Procedure Monologue Text, Demonstration Method

\begin{abstract}
ABSTRAK
Kenyataan di lapangan di Kelas IX-B SMP Negeri 3 Manonjaya, siswa kesulitan dalam menulis teks monolog procedure. Dengan demikian, untuk mengatasi kesulitan siswa dalam menulis teks monolog procedure perlu suatu cara untuk memudahkan siswa dalam melukiskan keadaan sebenarnya melalui kata-kata. Salah satu cara alternatif dalam menulis teks monolog procedure melalui metode demonstrasi. Oleh karena itu tujuan penelitian ini yaitu untuk mengetahui data peningkatan kemampuan menulis teks monolog procedure siswa melalui metode demonstrasi pada pembelajaran bahasa Inggris di Kelas IX-B SMP Negeri 3 Manonjaya. Metode yang akan digunakan dalam penelitian adalah Penelitian Tindakan Kelas (PTK) model Kemmis dan Taggart. Subjek dalam penelitian ini ialah guru dan siswa Kelas IX-B SMP Negeri 3 Manonjaya. Jumlah siswa Kelas IX-B sebanyak 29 orang, yang terdiri dari 14 orang laki-laki dan 15 orang perempuan. Hasil penelitian menunjukkan hasil belajar siswa tentang kemampuan siswa menulis teks monolog procedure melalui metode demonstrasi berpengaruh terhadap peningkatan hasil belajar siswa. Kemampuan siswa menulis teks monolog procedure setelah menggunakan metode demonstrasi pada pembelajaran bahasa dan sastra Inggris di Kelas IX-B SMP Negeri 3 Manonjaya terbukti mengalami peningkatan yaitu hasil belajar siswa siklus I yaitu $74,8 \%$ meningkat menjadi $82,8 \%$ pada siklus II.
\end{abstract}

Kata Kunci: Kemampuan, Teks Monolog Prosedur, Metode Demontrasi

Cara sitasi: Haryana, E. (2021). Upaya Meningkatkan Kemampuan Siswa dalam Menulis Teks Monolog Procedure melalui Metode Demonstrasi. J-KIP (Jurnal Keguruan dan IImu Pendidikan), 2 (3), 43-48. 


\section{PENDAHULUAN}

Pendidikan merupakan hal penting dalam rangka meningkatkan kualitas Sumber Daya Manusia baik dari segi spiritual, intelegensi, maupun skill untuk menunjang kehidupannya (Sopiah, Effendi \& Sunaryo ; 2020). Upaya meningkatkan proses pembelajaran harus dilaksanakan demi tercapainya tujuan penyelenggaraan pendidikan dasar karena inti dari peningkatan mutu pendidikan adalah terjadinya peningkatan kualitas dalam proses pembelajaran yang berlangsung di dalam kelas. Proses pembelajaran yang terjadi di sekolah masih banyak menggunakan pendekatan pembelajaran yang kurang memperhatikan kebutuhan dan pengembangan potensi siswa, serta cenderung bersifat sangat teoritik, peran guru masih sangat dominan (teacher centered), dan gaya mengajar cenderung bersifat satu arah. Penelitian ini menyebutkan bahwa proses pembelajaran yang terjadi hanya sebatas pada penyampaian informasi saja (transfer of knowledge), kurang terkait dengan lingkungan sehingga siswa tidak mampu memanfaatkan konsep kunci keilmuan dalam proses pemecahan masalah kehidupan yang dialami siswa sehari-hari.

Salah satu pembelajaran yang harus dikuasai siswa di kelas IX di SMP adalah menulis teks monolog procedure. Hal ini ditegaskan dalam kurikulum 2006 (Depdiknas, 2006) "Menulis secara efektif dan efisien berbagai jenis karangan narasi dalam berbagai konteks serta berapresiasi sastra dalam berbagai jenis dan bentuk melalui kegiatan menulis hasil sastra. Seperti menulis huruf, suku kata, kalimat, paragraf dengan tulisan yang rapi dan jelas, menulis karangan narasi sederhana, berbagai petunjuk, teks percakapan, surat pribadi dan surat resmi dengan memperhatikan tujuan dan ragam pembaca dan menggunakan ejaan dan tanda baca serta kosa kata yang tepat. Kompetensi menulis juga diarahkan menumbuhkan kebiasaan menulis.

Menulis teks monolog procedure adalah penggambaran suatu keadaan dengan kalimat-kalimat, sehingga menimbulkan kesan yang hidup. Penggambaran atau lukisan itu harus disajikan sehiduphidupnya, sehingga apa yang dilukiskan itu hidup di dalam angan-angan pembaca. Teks monolog procedure lebih menekankan pengungkapannya melalui rangkaian kata-kata.

Berdasarkan observasi di SMPN 3 Manonjaya, terlihat kemampuan menulis teks monolog prosedur siswa Kelas IX B tahun pelajaran 2017/2018 masih rendah. Kesulitan dalam menulis teks monolog procedure tersebut diantaranya dalam menentukan ide pokok (gagasan) dan menyusun kerangka tulisan berdasarkan maksud dan tujuan, serta khalayak pembacanya, menyalin ide pokok sesuai dengan kerangka tulisan dalam bentuk bahasa tulis, menyempurnakan tulisan dari aspek kebahsaan, penggunaan kata dan ejaan.

Dengan demikian, untuk mengatasi kesulitan siswa dalam menulis teks monolog procedure perlu suatu cara untuk memudahkan siswa dalam melukiskan keadaan sebenarnya melalui kata-kata. Salah satu cara alternatif dalam menulis teks monolog procedure melalui metode pembelajaran yang lebih tepat. Metode pembelajaran yang dianggap dapat meningkatkan hasil belajar adalah pembelajaran berbasis konstruktivisme, yaitu pembelajaran melalui aktivitas siswa yang proaktif dan reaktif dalam membangun pengetahuan melalui metode demonstrasi. Setiawan (2006), mengemukakan bahwa metode pembelajaran adalah melihat pembelajaran sebagai suatu desain yang menggambarkan proses rincian dan penciptaan situasi lingkungan yang memungkinkan siswa berinteraksi sehingga terjadi perubahan atau perkembangan pada diri siswa.

Metode demonstrasi merupakan suatu metode mengajar yang dapat digunakan dalam pembelajaran untuk meningkatkan dan membangkitkan motivasi kepada siswa. Selain itu dapat memberi kesempatan pada siswa untuk berlatih dengan kondisi terkontrol, sehingga proses pembelajaran dapat direfleksi setelah didemonstrasikan, maka pada akhir pelajaran penggunaan metode demonstrasi dapat digunakan untuk menilai hasil belajar siswa. Penilaian ini merupakan penilaian terhadap pengalaman langsung siswa. Dengan demikian, secara umum metode demonstrasi dalam proses pembelajaran 
dimaksudkan untuk meningkatkan keefektifan tercapainya tujuan pengajaran, karena metode demonstrasi dapat dilaksanakan sebagai suatu metode dalam proses pembelajaran.

Adapun efektifitas metode demonstrasi, siswa berkesempatan mengembangkan kemampuan mengamati segala benda yang sedang terlibat dalam proses serta dapat mengambil kesimpulankesimpulan yang diharapkan. Dalam demonstrasi diharapkan setiap langkah pembelajaran dari hal-hal yang didemonstrasikan itu dapat dilihat dengan mudah oleh siswa dan melalui prosedur yang benar dan dapat pula dimengerti materi yang diajarkan.

Berdasarkan hal tersebut, penulis melakukan Penelitian Tindakan Kelas dengan judul : Upaya Meningkatkan Kemampuan Siswa dalam Menulis Teks Monolog Procedure melalui Metode demonstrasi (Penelitian Tindakan Kelas pada Pembelajaran Bahasa Inggris di Kelas IX-B SMP Negeri 3 Manonjaya Tahun Pelajaran 2017/2018).

\section{METODE PENELITIAN}

Metode yang akan digunakan dalam penelitian adalah jenis Penelitian Tindakan Kelas (PTK) model Kemmis dan Taggart. Lokasi penelitian ini adalah SMP Negeri 3 Manonjaya. Alasan lokasi penelitian ini antara lain : (1) Baik guru dan Kepala Sekolah maupun pejabat yang terkait memberikan izin dilaksanakannya penelitian di SMPN tersebut, (2) Lokasi penelitian sebagai tempat mengajar penulis.

Subjek dalam penelitian ini ialah guru dan siswa Kelas IX-B SMP Negeri 3 Manonjaya. Jumlah siswa Kelas IX-B sebanyak 29 orang, yang terdiri dari 14 orang laki-laki dan 15 orang perempuan. Fokus Penelitian Tindakan Kelas (PTK), adalah sebagai berikut :

1) Kinerja Guru

a. Meningkatkan perencanaan pembelajaran melalui metode demonstrasi pada pembelajaran menulis teks monolog procedure di Kelas IX-B SMP Negeri 3 Manonjaya.

b. Meningkatkan proses pelaksanaan pembelajaran melalui metode demonstrasi pada pembelajaran menulis teks monolog procedure di Kelas IX-B SMP Negeri 3 Manonjaya.

2) Aktivitas dan Hasil belajar Siswa

a. Meningkatkan Pembelajaran Bahasa Inggris di Kelas IX-B SMP Negeri 3 Manonjaya.

b. Meningkatkan hasil belajar siswa melalui metode demonstrasi pada pembelajaran menulis teks monolog procedure di Kelas IX-B SMP Negeri 3 Manonjaya.

Instrumen yang digunakan untuk mengumpulkan data dalam tindakan penelitian ini adalah :

a) Tes tertulis dilakukan pada awal dan akhir pembelajaran tes yang dilakukan pada awal pembelajaran disebut pretest dengan tujuan untuk mengetahui konsepsi awal pemahaman siswa terhadap materi pembelajaran sebelum dilakukan tindakan, sedangkan test yang dilakukan di akhir pembelajaran disebut postest dengan tujuan untuk mengetahui pemahaman siswa terhadap materi pembelajaran setelah dilakukan tindakan.

b) Observasi, observasi dalam kegiatan belajar mengajar dilakukan dengan tujuan untuk memperoleh gambaran, baik bersifat umum, maupun khusus yang berkenaan dengan aspek-aspek proses pendekatan yang dikembangkan. Aspek yang di observasi diantaranya ialah aktivitas siswa dalam belajar dan aktifitas guru dalam perencanaan dan pelaksanaan pembelajaran.

Jumlah siklus yang dilaksanakan sebanyak dua yaitu Siklus I dan Siklus II.

\section{HASIL PENELITIAN DAN PEMBAHASAN}

Rencana Pelaksanaan Pembelajaran yang disusun untuk pelaksanaan tindakan pertama sebagian besar telah memenuhi standar yang diharapkan, seperti diuraikan pada bagian analisis data hasil penelitian. Hasil observasi perencanaan dalam bentuk perencanaan pembelajaran mencapai $70 \%$ dari keseluruhan aspek yang dinilai dalam rencana pelaksanaan pembelajaran. Hal ini menunjukkan bahwa 
perencanaan pada siklus I belum nemenuhi target yang ditetapkan $75 \%$. Kekurangan dalam rencana Pelaksanaan Pembelajaran, yaitu pada aspek bahan pembelajaran, indikator menyiapkan dengan jelas materi pembentukan sikap dan perilaku masih kurang. Pada aspek strategi pembelajaran, indikator alokasi waktu untuk fase-fase belum tersusun secara proporsional. Pada aspek evaluasi, indikator pengaturan alokasi waktu belum proporsional.

Hasil observasi perencanaan dalam bentuk perencanaan pembelajaran pada siklus II mencapai $88,7 \%$ dari keseluruhan aspek yang dinilai dalam rencana pelaksanaan pembelajaran. Hal ini menunjukkan bahwa perencanaan pada siklus II sudah melebihi target yang ditetapkan $75 \%$. Sehubungan dengan uraian di atas, dapat dijelaskan bahwa rencana pembelajaran terlihat adanya perubahan ke arah penyempurnaan. Hal ini di buktikan dengan peningkatan prosentase nilai rencana pembelajaran. Rencana pembelajaran tindakan pertama mendapat skor $70 \%$, sedangkan rencana pembelajaran kedua dengan prosentase $88,7 \%$. Hal ini merupakan salah satu faktor meningkatnya kemampuan belajar siswa pada pembelajaran dengan metode demonstrasi.

\section{Tindakan Perbaikan Pembelajaran}

Pembahasan tindakan perbakian pembelajaran difokuskan pada perbandingan aktivitas guru dan siswa pada tindakan pertama dengan aktivitas guru dan siswa pada tindakan kedua. Pelaksanaan pembelajaran yang dilaksanakan oleh guru pada siklus I belum memenuhi target (75\%) yaitu 72,9\% dari seluruh aspek yang diamati.

Kekurangan pelaksanaan pembelajaran siklus I pada aktivitas guru, yaitu pada aspek membuka pembelajaran guru belum menyampaikan materi secara garis besar. Pada aspek kegiatan inti, guru kurang melakukan tanya jawab mengenai hal-hal kesalahan-kesalahan dalam penyusunan teks monolog procedure. Pada aspek menutup pembelajaran, guru kurang mengkondisikan siswa untuk pembelajaran berikutnya. Sedangkan aktivitas siswa, pada aspek kegiatan inti, siswa kurang melakukan refeleksi dari pengalaman belajar, dan kurang nampak proses tanya jawab mengenai kesalahan-kesalahan dalam penyusunan teks monolog procedure. Pada aspek menutup pembelajaran, siswa kurang mengkondisikan diri untuk pembelajaran berikutnya. Pelaksanaan pembelajaran yang dilaksanakan oleh guru pada siklus II sudah melampaui target (75\%) yaitu 95,8\% dari seluruh aspek yang diamati.

Pelaksanaan pembelajaran yang dilakukan siswa pada siklus I belum memenuhi target, baru mencapai $72,5 \%$, untuk kegiatan awal dan akhir sudah mencapai target yakni $81,25 \%$, namun untuk kegiatan intinya baru mencapai 68,75\%.

Berdasarkan hasil peneltian tersebut, bahwa pada siklus I beberapa siswa terlihat tidak antusias, mereka tampak canggung untuk mengutarakan pendapat pada saat pengumpulan informasi pada pembelajaran menulis teks monolog procedure khususnya pada pengumpulan informasi teks monolog procedure perpisahan. Tampak juga beberapa siswa yang ditunjuk tidak mau untuk membacakan hasil belajar mereka yaitu menulis teks monolog procedure.

Pelaksanaan pembelajaran yang dilakukan siswa pada siklus II sudah memenuhi target sebesar $89,5 \%$, untuk kegiatan awal dan akhir sudah mencapai target yakni 93,75\%, dan untuk kegiatan inti mencapai target $79,1 \%$. Hal ini menunjukkan bahwa praktisi telah memberikan penjelasan dan pengarahan yang mendalam pada saat pengumpulan informasi mengenai hal-hal yang terdapat pada teks monolog procedure. Selain itu praktisi telah memotivasi siswa untuk bangga dengan hasil kerja mereka, sehingga ketika praktisi menugaskan pada siswa untuk membacakan hasil kerjanya, mereka tampak antusias dalam membacakan hasil kerja mereka.

\section{Hasil Belajar Siswa}

Hasil belajar siswa secara keseluruhan dapat diuraikan dengan membandingkan nilai postes pada tindakan pertama dengan nilai postes pada tindakan kedua. 
Dari 29 orang siswa, ternyata nilai postes tindakan pertama mendapat nilai rata-rata 74,8 atau $(74,8 \%)$, sedangkan nilai postes tindakan kedua mendapat nilai rata-rata 82,8 atau $(82,8 \%)$.

Perbedaan nilai rata-rata tindakan pertama dengan nilai rata-rata tindakan kedua adalah sebesar $8 \%$. Seperti tercantum pada tabel di atas, nilai rata-rata siswa pada hasil belajar tindakan pertama sebesar $74,8 \%$, sedangkan nilai rata-rata hasil belajar pada tindakan kedua sebesar $82,8 \%$. Jika dianalisa perbedaan nilai antara tindakan pertama dan kedua hanya sebesar $8 \%$, tetapi hal ini menunjukan adanya perubahan yang lebih baik.

Gambaran umum perbandingan hasil pelaksanaan pembelajaran siklus I dan II yang menyangkut aspek rencana pembelajaran, aktivitas guru dan siswa serta hasil belajar siswa selengkapnya dapat dilihat pada Tabel 1.

Tabel 1. Rekafitulasi Hasil Pelaksanaan Siklus I dengan Siklus II

\begin{tabular}{|c|c|c|}
\hline Aspek Tindakan & Siklus I & Siklus II \\
\hline Rencana Pembelajaran & $\begin{array}{l}\text { Rencana pelaksanaan } \\
\text { pembelajaran siklus I dengan } \\
\text { persentase } 70 \%\end{array}$ & $\begin{array}{l}\text { Rencana pelaksanaan } \\
\text { pembelajaran siklus II dengan } \\
\text { persentase } 88,7 \%\end{array}$ \\
\hline Aktivitas Guru & $\begin{array}{llr}\text { Aktivitas } & \text { guru } & \text { dalam } \\
\text { pembelajaran } & \text { siklus I } & \text { dengan } \\
\text { persentase } 72,9 \% & \end{array}$ & $\begin{array}{l}\text { Aktivitas guru } \quad \text { dalam } \\
\text { pembelajaran } \\
\text { persentase } 95,8 \%\end{array}$ \\
\hline Aktivitas siswa & $\begin{array}{l}\text { Aktivitas siswa } \\
\text { pembelajaran siklus I dengan } \\
\text { persentase } 64,5 \%\end{array}$ & $\begin{array}{l}\text { Aktivitas siswa } \\
\text { pembelajaran } \\
\text { persentus } \text { II } \\
\text { persengan } \\
89,5 \%\end{array}$ \\
\hline Hasil Belajar Siswa & $\begin{array}{l}\text { Hasil belajar siswa siklus I } \\
\text { dengan persentase atau } 74,8 \%\end{array}$ & $\begin{array}{l}\text { Hasil belajar siswa siklus II } \\
\text { dengan persentase } 82,8 \%\end{array}$ \\
\hline
\end{tabular}

Adapun grafik hasil pelaksanaan siklus I dan II, disajikan pada Gambar 1.
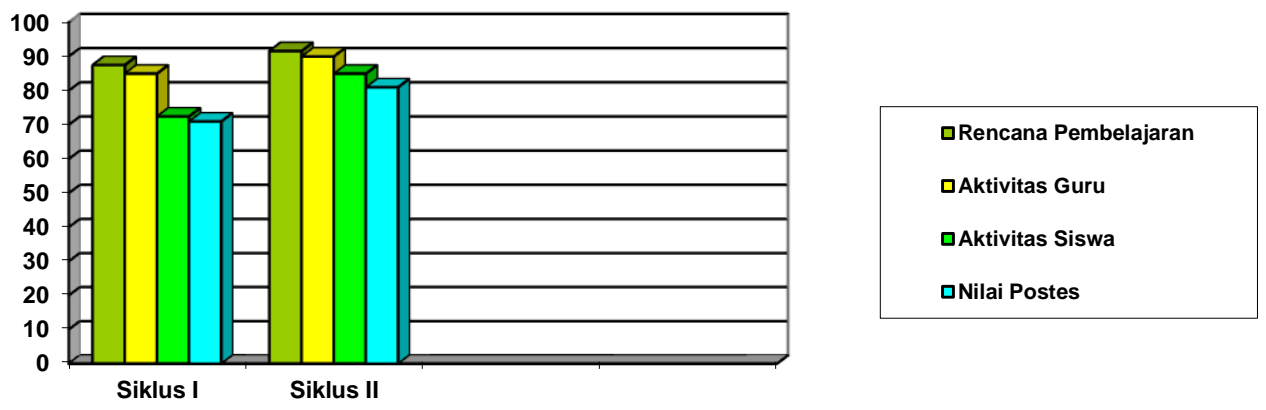

\section{Gambar 1. Hasil Pelaksanaan Siklus I Dan II}

Berdasarkan Gambar 1, bahwa keterampilan menulis teks monolog procedure mengalami peningkatan, karena perencanaan dan proses pelaksanaan pembelajaran yang diterapkan oleh guru lebih efektif dengan menggunakan metode demonstrasi”.

\section{KESIMPULAN}

Kesimpulan yang diperoleh berdasarkan pembahasan hasil penelitian tentang meningkatkan kemampuan siswa menulis teks monolog procedure melalui metode demonstrasi pada pembelajaran bahasa dan sastra Inggris di Kelas IX-B SMP Negeri 3 Manonjaya, adalah sebagai barikut: 
1. Perencanaan pembelajaran dalam meningkatkan kemampuan siswa menulis teks monolog procedure melalui metode demonstrasi pada pembelajaran bahasa dan sastra Inggris di Kelas IX-B SMP Negeri 3 Manonjaya, memperoleh hasil bahwa Rencana Pelaksanaan Pembelajaran (RPP) siklus I belum optimal, sedangkan Rencana Pelaksanaan Pembelajaran (RPP) siklus II terdapat peningkatan kinerja guru dalam menyusun Rencana Pelaksanaan Pembelajaran berpengaruh terhadap peningkatkan hasil belajar siswa tentang kemampuan siswa menulis menulis teks monolog procedure.

2. Proses pembelajaran dalam meningkatkan kemampuan siswa menulis teks monolog procedure melalui metode demonstrasi pada pembelajaran bahasa dan sastra Inggris di Kelas IX-B SMP Negeri 3 Manonjaya, bahwa aktivitas guru dalam pembelajaran siklus I belum optimal, sedangkan pada siklus II aktivitas guru dan siswa dalam pelaksanaan pembelajaran mengalami peningkatan. Hal ini berarti bahwa hasil belajar siswa tentang kemampuan siswa menulis teks monolog procedure melalui metode demonstrasi berpengaruh terhadap peningkatan hasil belajar siswa.

3. Kemampuan siswa menulis teks monolog procedure setelah menggunakan metode demonstrasi pada pembelajaran bahasa dan sastra Inggris di Kelas IX-B SMP Negeri 3 Manonjaya terbukti mengalami peningkatan yaitu hasil belajar siswa siklus I yaitu $74,8 \%$ meningkat menjadi $82,8 \%$ pada siklus II.

\section{REKOMENDASI}

Dalam penyampaian materi pelajaran hendaknya tidak langsung pada materi pokok, kecuali kalau materi-materi prasyaratnya telah terkuasai siswa untuk itu perlu mengoreksi dahulu kemampuan dan pemahaman siswa terhadap materi tersebut.

\section{UCAPAN TERIMAKASIH}

Ucapan terimakasih penulis tujukan kepada pihak-pihak yang telah membantu dalam penelitian ini yaitu siswa kelas IX-B SMP Negeri 3 Manonjaya.

\section{DAFTAR PUSTAKA}

Depdiknas. (2006). Permendiknas No 22 Tahun 2006 Tentang Standar Isi. Jakarta : Depdiknas.

Setiawan, A. (2006), Pengantar Statistika, Graha Ilmu, Yogyakarta.

Sopiah, E, S., Effendi, A., \& Sunaryo, Y. (2020). Analisis Kemampuan Berpikir Kreatif Matematis Siswa Kelas VIII pada Materi Sistem Persamaan Linear Dua Variabel (SPLDV). J-KIP (Jurnal Keguruan dan IImu Pendidikan) , 1 (2), 1-10.

Tim Pelatih PGSM. (1999). PTK Penelitian. Jakarta : Depdikbud. 